\title{
The Effects of Paracetamol and Ibuprofen on Smooth Muscle Response of the Bronchospasm: an in Vitro Study
}

\author{
Parasetamol ve ibuprofenin Bronkospazm Oluşturulmuş Bronş \\ Düz Kas Dokusunda Etkileri: in Vitro Çalışma
}

\author{
Ali Onur Erdem ${ }^{1}$, Kamil Varlık Erel ${ }^{2}$, Sezen Özkısacık ${ }^{1}$, Mesut Yazıcı ${ }^{1}$ \\ ${ }^{1}$ Aydın Adnan Menderes University Faculty of Medicine, Department of Pediatric Surgery, Aydın, Turkey \\ ${ }^{2}$ Aydın Adnan Menderes University Faculty of Medicine, Department of Anesthesiology and Reanimation, Aydın, Turkey
}

Keywords

Ibuprofen, paracetamol, bronchus, isolated tissue bath, bronchospasm, in vitro study

\begin{abstract}
Anahtar Kelimeler
İbuprofen, paracetamol, bronş, izole organ banyosu, bronkospazm, in vitro çalışma
\end{abstract}

Received/Geliş Tarihi : 19.03.2018

Accepted/Kabul Tarihi : 12.10.2018

doi:10.4274/meandros.72692

Address for Correspondence/Yazışma Adresi: Ali Onur Erdem MD Aydın Adnan Menderes University Faculty of Medicine, Department of Pediatric Surgery, Aydın, Turkey

Phone : +90 2562181850

E-mail : aoerdem@adu.edu.tr

(C) Meandros Medical and Dental Journal, Published by Galenos Publishing.

This is article distributed under the terms of the Creative Commons Attribution NonCommercial 4.0 International Licence (CC BY-NC 4.0).

\begin{abstract}
Objective: Bronchospasm is a very important complication that can be encountered during the postoperative and intraoperative periods. This complication may be caused by surgery, anesthesia, or patient-related issues. Many analgesics are preferred during the intraoperative period for postoperative analgesia. In this study, we aimed to investigate the effects of ibuprofen and paracetamol on rat bronchus with supramaximal tonus as a model of bronchospasm under in vitro conditions.

Materials and Methods: Totally, 20 male rats were used in our study. After the ketamine anesthesia, the left main bronchus of each rat was removed and suspended in the organ bath in Krebs solution. Four rat bronchi were excluded because of not demonstrating viability with atropine and acetylcholine. After demonstrating the viability of the rats' bronchi $(n=16)$, acetylcholine was applied to produce supramaximal contraction. The rats' bronchi with supramaximal contraction were randomly divided into two groups. Paracetamol was applied to Group 1, and ibuprofen to Group 2. The contraction responses of each group were recorded and compared statistically.

Results: While a statistical significance was not detected regarding the supramaximal contraction in Group 1 with a mean of $0.18 \pm 0.07 \%$ ( $p>0.05)$, tonus was reduced to $6.79 \pm 0.28 \%(p<0.05)$ in Group 2, and the relaxation response reached the baseline tonus in this group.

Conclusion: Intraoperative analgesia is very important in preventing postoperative complications and ensuring patient comfort. In general, opioids and concomitant NSAI or paracetamol group drugs are preferred intraoperatively for postoperative analgesia. In our study, although there was no effect of paracetamol on rat bronchi with supramaximal tonus, ibuprofen showed an unexpected significant relaxation response. In conclusion, ibuprofen may be preferred much more the than paracetamol in patients with high risk of clinical bronchospasm.
\end{abstract}

Öz

Amaç: Bronkospazm postoperastif ve intraoperatif dönem boyunca karşılaşılabilen çok önemli bir komplikasyondur. Bu komplikasyon cerrahi, anestezi ve hastaya ait nedenlerle oluşabilmektedir. Postoperatif analjezi oluşturmak için intraoperatif dönemde rutinde pek çok analjezik tercih edilmektedir. Bizde bu çalışmada invitro şartlarda bir bronkospazm modeli olarak supramaksimal tonuslü rat trakeasında intravenöz analjeziklerden ibuprofen ve parasetamolün etkilerini görmeyi amaçladık. 
Gereç ve Yöntemler: Çalışmamızda toplam 20 erkek rat kullanıldı. Ketamin anestezisi sonrası her ratın sol ana bronşları çıkarılarak krebs solusyonunda organ banyosuna asıldı. Dört rat bronşu asetilkolin ve atropine cevap alınamadığı için çalışma dışı bırakıldı. Canlılığı kanıtlanan rat bronşlarına $(n=16)$ asetilkolin uygulanarak supramaksimal kontraksiyon oluşturuldu. Supramaksimal kontraksiyon oluşturulan rat bronşları randomize olarak iki gruba ayrıldı. grup 1'e $(n=8)$ parasetamol, grup 2'e $(n=8)$ ibuprofen uygulandı. Her bir grubun kontraksiyon cevapları kaydedildi ve sonra istatistiksel olarak karşılaştırıldı.

Bulgular: Supramaksimal kontraksiyonda grup 1' de ortalama \%0,18 0,07 ile istatistiksel olarak anlamlı bir değişiklik saptanmazken ( $p>0.05)$ grup 2'de ortalama \%6,79 $\pm 0,28(p<0.05)$ tonusu düşüşü izlenerek bazal değerlere indiği belirlendi.

Sonuç: İntraoperatif analjezi postoperatif komplikasyonların önlenmesinde ve hasta konforunun sağlanmasında çok önemlidir. Genel olarak postoperatif analjezi için intraoperatif olarak opioidler ve beraberinde NSAI veya parasetamol grubu ilaçlar tercih edilmektedir. Çalışmamızda tonusu artırılmış bronş dokusunda "in vitro bronkospazm modeli" parasetamolun herhangi etkisi olmazken, iboprofenin beklenilenin aksine istatistiksel olarak anlamlı oranda gevşeme cevabı verdiğini saptadık. Sonuç olarak eğer in vivo çalışmalarla da desteklenirse klinik olarak bronkospazm riski yüksek olan hastalarda ibuprofenin parasetamolden daha öncelikli olarak tercih edilebileceğini düşünmekteyiz.

\section{Introduction}

Airway spasms are common and increase surgical risk (1-3). Bronchospasm is an undesirable phenomenon in all phases of operation and anesthesia. There are also studies supporting that endotracheal intubation and general anesthetic agents increase the incidence of bronchospasm and postoperative bronchospasm by $20 \%$ for both regional and general anesthesia $(4,5)$. Many studies have also been conducted on pediatric surgical patients, in whom one of the major concerns of anesthesiologists is the identification of perioperative respiratory adverse events and associated risk factors (6). Especially in interventions as removal of respiratory foreign body and procedures associated with the upper respiratory tract, this risk is increasing $(7,8)$. Intravenous analgesics are often preferred in postoperative pain prophylaxis. However, in the literature, the bronchospasm risk of these intravenous analgesics is small. In this study, we tried to show concrete effects of ibuprofen and paracetamol, and we applied the model of bronchospasm to the bronchial smooth muscle of rat bronchus which was simulated under in vitro conditions.

\section{Materials and Methods}

Twenty male rats (four to six-month-old, about 350-400g) were obtained from Experimental Animal Center of Adnan Menderes University (ADU), and all experiments were performed in accordance with the principles and guidelines of ADU Animal Ethical Committee's approval (HADYEK 64583101/2016/56).

\section{Experimental Model}

Krebs-Henseleit solution contains (g/L): glucose 2, MgSO4 0.41, KPO4 0.16, $\mathrm{KCl} 0.35, \mathrm{NaCl}$ 6.9,
$\mathrm{CaCl}$ 0.373, NaHCO3 2.1 (ph: 7.4) in isolated tissue bath. The buffer solution was oxygenated with $95 \%$ $\mathrm{O}_{2}$ and $5 \% \mathrm{CO}_{2}$. During the equilibrium period in the organ bath, the Krebs solution of the organ bath was washed for four times in one hour (once a 15-minuteperiod), $1 \mathrm{~g}$ basal tension was slowly supplied. All rats were anesthetized with $50 \mathrm{mg} / \mathrm{kg}$ ketamine. After the anesthesia, while heartbeat was continuing, trachea and left main bronchus were removed with thoracotomy and sternotomy as rings sized $3 \mathrm{~mm}$ and suspended with $1 \mathrm{~g}$ rest tension in $10 \mathrm{ml}$ organ bath.

After the left main bronchi of rats were removed, all rats were decapitated and sacrificed. Isometric contractions of circular smooth muscles were measured with the MAY FDT $10-A{ }^{\circledR}$ transducer. After the viability of the tissues was demonstrated with acetylcholine and atropine, washed tissues were kept waiting until they reached the basal tonus. Four rat bronchi were excluded from the study because of not demonstrating viability with atropine and acetylcholine. The bronchi that completed these steps were considered as alive. After demonstrating the viability of the rat bronchi ( $n=16)$, acetylcholine (Ach) was applied to produce supramaximal contraction. 16 rats, which produced at least $7 \%$ increase in Ach supramaximal contraction and provided a plateau for at least 15 minutes were included in the study. Two groups were assigned to a random number table. Paracetamol $\left(1 \times 10^{-1} \mathrm{M}\right)$ was administered to Group 1 in the supramaximal contraction and ibuprofen $\left(1 \times 10^{-1} \mathrm{M}\right)$ in Group 2 in the supramaximal contraction. The results were recorded in the Acknowledge MP $100{ }^{\circledR}$ program.

\section{Statistical Analysis}

The normality test of tonus, before and after administering to the groups of ibuprofen and 
paracetamol, was performed by Kolmogorov-Smirnov test and data were log transformed for normal distribution. After logarithmic transformation data were normally distributed. All data were shown as mean, standard deviation, and $95 \%$ confidence interval $[\mathrm{Cl}]$. Comparisons of pre- and postmeasurements in each drug were made using the Paired Sample t-test for normally distributed data in groups. The comparisons of relaxion rate of two drugs were done by using independent samples T-test. SPSS 22.0 program were used and $p<0.05$ was considered statistically significant.

\section{Results}

In the $10 \mathrm{mmol}$ group of ibuprofen, it was determined that the level of supramaximal tonus was at $0.41 \pm 0.93$ before implementation, which decreased to the level of $0.34 \pm 0.90$ after implementation. The reduction in tonus was statistically significant (estimated mean difference, $-0.41 ; 95 \%$ confidence interval $[\mathrm{Cl}], 0.038$ to $0.092 ; \mathrm{p}=0.001$ (Figure 1 ). Mean tonus decrease rate for ibuprofen was $1.423 \pm 0.2 \%$ (Figure 2).

However, in the $20 \mathrm{mmol}$ group of paracetamol, level of supramaximal tonus was at $0.20 \pm 0.85$ before implementation, which had no change in the level of $0.20 \pm 0.85$ after implementation. The difference was not statistically significant (estimated mean

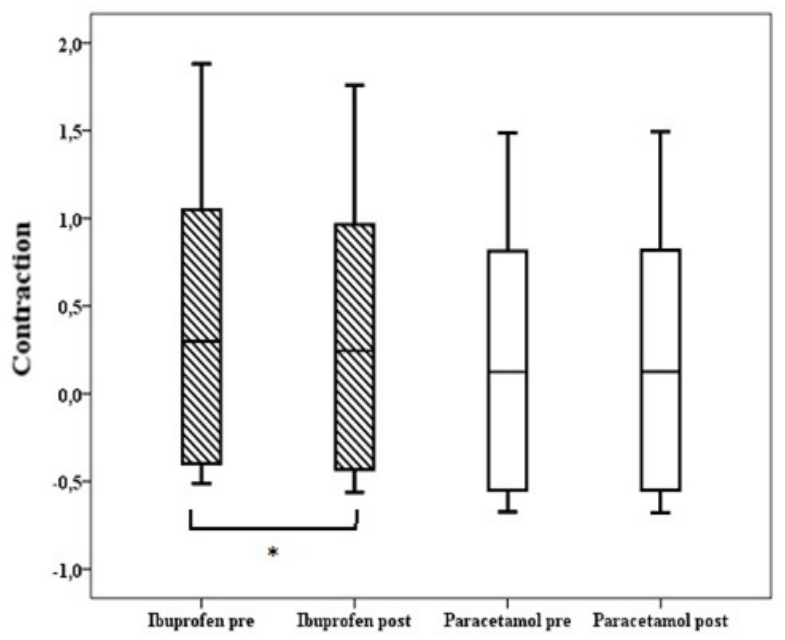

Figure 1. Box plot representing the initial (pre) and last (post) \% contractions of bronchioles after Ibuprofen and Paracetamol. Ends of the whiskers represent the 10th and the 90th percentiles. Horizontal lines represent mean values. Paired sample t-test results. ${ }^{*} p<0,001$ difference, $0.20 ; 95 \%$ confidence interval $[\mathrm{Cl}],-0.006$ to $0.002 ; p=0.340$ ) (Figure 1). Mean tonus change rate for paracetamol was $0.213 \pm 0.6 \%$ (Figure 2 ).

In the paracetamol group, the duration of reaching supramaximal contraction after acetylcholine was $190 \pm 5$ seconds, while $180 \pm 4$ seconds in the ibuprofen group but there was no statistical significance ( $>0.05$ ). (Figure 3). In Group 1, supramaximal tonus after paracetamol could be kept for $500 \mathrm{~s}$ (Figure 3).

After ibuprofen administration, it showed a relaxation, down to much below from baseline tonus before acetylcholine, within a mean of $270 \pm 8 \mathrm{~s}$ and this tonus was preserved for $500 \mathrm{~s}$ (Figure 3 ).

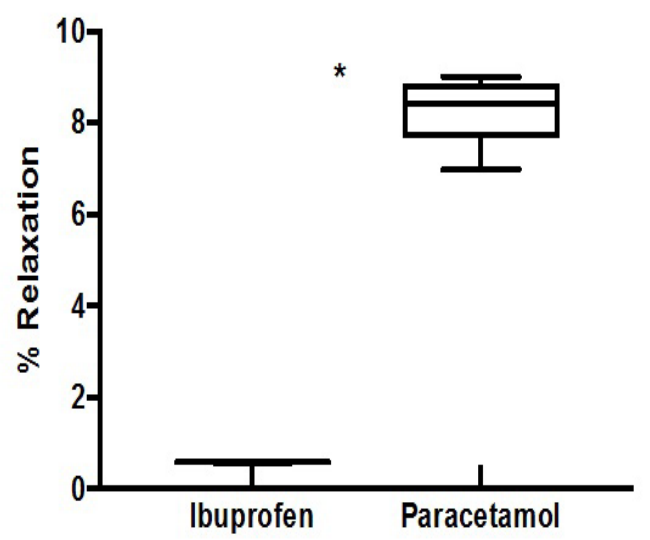

Figure 2. The relaxation rate of groups after supramaximal contraction. ${ }^{*} \mathrm{p}<0.001$

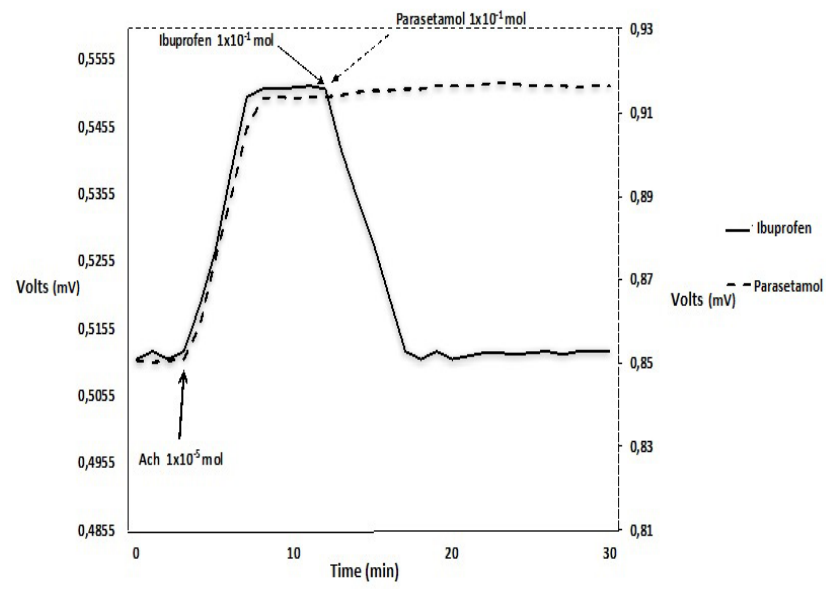

Figure 3. The effects of Ibuprofen and Paracetamol on alteration of Ach-induced contractile response. Straight line denotes the contraction changes on Ibuprofen. The dotted line denotes the contraction changes on Paracetamol 


\section{Discussion}

In our experimental study, we found that ibuprofen gave a response as a muscle relaxation in contrast to the expected increase in supramaximal bronchial muscle tissue tonus. Paracetamol did not cause any change in muscle tone.

In this study, we measured the smooth muscle response of the bronchial tissue to ibuprofen and paracetamol, which we use most frequently for analgesic purposes, under in vitro conditions, in the organ bath. We evaluated the responses obtained with ibuprofen and paracetamol, which we added in supramaximal contractions after increasing tonus of bronchial tissue to simulate bronchospasm. We found no muscle response to paracetamol in the smooth muscle of the bronchus, while ibuprofen caused a significant muscle relaxant response in the smooth muscle of the bronchus in the supramaximally contracted state.

Airway spasm is very common and one of the most important and life-threatening complications. Regarding the etiology of this spasm, there is a wide range of causes, from an upper respiratory tract infection to an underlying allergic reaction to anesthetic medications. Except for the predictable ones, the sudden and unpredictable development of airway spasm, which is a serious problem for both the surgeon and the anesthetist, is not less at all. (9)

NSAID drugs show their analgesic and antiinflammatory effects by inhibiting COX-1 and COX-2. Inhibition of these enzymes inhibits the release of pathogenic inflammatory and physiological mediators (10). There are many clinical studies showing that ibuprofen increases the frequency and morbidity of bronchospasm, resulting in exacerbations in asthmatic patients (11-13). Some investigators have reported severe and fatal asthma attacks due to ibuprofen (14; 15).

In recent years, the risk of acute bronchospasm induced by ibuprofen in children with asthma has been questioned. There is little evidence related to the increased morbidity in pediatric asthmatic patients. In addition, the inflammatory pathogenesis of asthma can reduce morbidity in asthmatic children due to the anti-inflammatory effect of ibuprofen. This feature of ibuprofen causes an interesting possibility of therapeutic benefit, at least for some children with asthma. (16) In an in vivo study, non-steroidal pharmaceuticals have been shown to result in reduced guinea-pig tracheal tone by inhibition of intramural biosynthesis of prostaglandins (17). In another study, following oral administration of ibuprofen resulted in a $45 \%$ to $80 \%$ improvement in forced expiratory volume (FEV 1) in spirometric measures (18). Because airway responses occur through many different mechanisms, the airway responses of ibuprofen obtained in clinical trials show differences. In our experimental study, we objectively have shown that bronchial smooth muscle tissue shows distinctive muscular relaxation with ibuprofen in the bronchial tissue bath.

Paracetamol appears to be the most reliable analgesic preparation in analgesic-dependent bronchospasm risk (esp. in asthmatic cases) (19). In our study, it caused no effect on the supramaximal tonus of the bronchial smooth muscle cells. In a study by Corominas et al., a paracetamol-induced asthma attack was mentioned (20). In some meta-analyses, associations seem to be present between paracetamol use and asthma development, and paracetamol has been reported to increase asthma risk by a factor of 6 $(21 ; 22)$. A long-lasting relationship between asthma/ chronic airway spasm and paracetamol has been shown in publications, but it is evident that its acute use is reliable in patients who are not at risk. In our experimental study, we applied that paracetamol on the bronchial tissue in supramaximal tonus and did not get any muscular response.

Ibuprofen and paracetamol have both oral and IV preparations. Oral or IV use does not alter their bioavailability (23). However, there are a limited number of available analgesic agents via I.V. route. There are many clinical studies showing the difference of effects of ibuprofen, paracetamol, and I.V. analgesics on airway spasms(24). There is no organ bath study that demonstrates the effects of the drugs on specific bronchial muscle tissue. We compared the effects of two drugs on the bronchial smooth muscle at supramaximal contraction. Both analgesics did not cause an increase in muscle tone of the bronchial smooth muscle. Ibuprofen was shown to give a significant relaxation response when compared to paracetamol. In the light of these data, ibuprofen is more effective than paracetamol for the relaxation of the contracted bronchial smooth muscle. 
Although with this study, we were able to accomplish objective measurements of the effects of a single dose of the drugs on tonus-enhanced bronchial tissue, it needs to be supported by clinical studies measuring and comparing the effects of different doses on various airway tissues with different tonus.

\section{References}

1. Canet J, Gallart L, Gomar C, Paluzie G, Valles J, Castillo J, Sabate S, Mazo V, Briones Z, Sanchis J: Prediction of postoperative pulmonary complications in a population-based surgical cohort. Anesthesiology 2010;113(6):1338-1350.

2. Shander A, Fleisher LA, Barie PS, Bigatello LM, Sladen RN, Watson $\mathrm{CB}$ : Clinical and economic burden of postoperative pulmonary complications: patient safety summit on definition, risk-reducing interventions, and preventive strategies. Crit Care Med 2011;39(9):2163-2172.

3. Subramanyam R, Yeramaneni S, Hossain MM, Anneken AM, Varughese AM: Perioperative Respiratory Adverse Events in Pediatric Ambulatory Anesthesia: Development and Validation of a Risk Prediction Tool. Anesth Analg 2016;122(5):1578-1585.

4. Kumeta Y, Hattori A, Mimura M, Kishikawa K, Namiki A: [A survey of perioperative bronchospasm in 105 patients with reactive airway disease]. Masui 1995;44(3):396-401.

5. Pappas AL, Sukhani R, Lurie J, Pawlowski J, Sawicki K, Corsino $A$ : Severity of airway hyperreactivity associated with laryngeal mask airway removal: correlation with volatile anesthetic choice and depth of anesthesia. J Clin Anesth 2001;13(7):498-503.

6. August DA, Everett LL: Pediatric ambulatory anesthesia. Anesthesiol Clin 2014;32(2):411-429.

7. Ciftci AO, Bingol-Kologlu $M$, Senocak ME, Tanyel FC, Buyukpamukcu N: Bronchoscopy for evaluation of foreign body aspiration in children. J Pediatr Surg 2003;38(8):1170-1176.

8. Zhijun C, Fugao Z, Niankai Z, Jingjing C: Therapeutic experience from 1428 patients with pediatric tracheobronchial foreign body. J Pediatr Surg 2008;43(4):718-721.

9. Li CQ, Wang DX, Cheng T, Zheng XY: [Effects of recent upper respiratory-tract infections on incidence of the perioperative respiratory adverse events in children: a prospective cohort study]. Beijing Da Xue Xue Bao Yi Xue Ban 2017;49(5):814-818.

10. Brzozowski T, Konturek PC, Konturek SJ, Brzozowska I, Pawlik $\mathrm{T}$ : Role of prostaglandins in gastroprotection and gastric adaptation. J Physiol Pharmacol 2005;56 ( 5):33-55.
11. Debley JS, Carter ER, Gibson RL, Rosenfeld M, Redding GJ: The prevalence of ibuprofen-sensitive asthma in children: a randomized controlled bronchoprovocation challenge study. J Pediatr 2005;147(2):233-238.

12. Lesko SM, Louik C, Vezina RM, Mitchell AA: Asthma morbidity after the short-term use of ibuprofen in children. Pediatrics 2002;109(2):E20.

13. Sanchez-Borges $M$, Capriles-Behrens E, Caballero-Fonseca $F$ : Hypersensitivity to non-steroidal anti-inflammatory drugs in childhood. Pediatr Allergy Immunol 2004;15(4):376-380.

14. Antonicelli L, Tagliabracci A: Asthma death induced by ibuprofen. Monaldi Arch Chest Dis 1995;50(4):276-278.

15. Ayres JG, Fleming DM, Whittington RM: Asthma death due to ibuprofen. Lancet 1987;1(8541):1082.

16. Kauffman RE, Lieh-Lai M: Ibuprofen and increased morbidity in children with asthma: fact or fiction? Paediatr Drugs 2004;6(5):267-272.

17. Ono T, Ohtsuka M, Sakai S, Ohno S, Kumada S: Relaxant effect of aspirin-like drugs on isolated guinea pig tracheal chain. Jpn J Pharmacol 1977;27(6):889-898.

18. Kordansky D, Adkinson NF, Jr., Norman PS, Rosenthal RR: Asthma improved by nonsteroidal anti-inflammatory drugs. Ann Intern Med 1978;88(4):508-511.

19. Karakaya G, Kalyoncu AF: Paracetamol and asthma. Expert Opin Pharmacother 2003;4(1):13-21.

20. Corominas M, Lleonart R, Munoz E: Bronchospasm induced selectively by paracetamol. J Investig Allergol Clin Immunol 2012;22(1):70-71.

21. Etminan $M$, Sadatsafavi M, Jafari S, Doyle-Waters $M$, Aminzadeh $\mathrm{K}$, FitzGerald JM: Acetaminophen use and the risk of asthma in children and adults: a systematic review and metaanalysis. Chest 2009;136(5):1316-1323.

22. Gonzalez-Barcala FJ, Pertega S, Perez CT, Sampedro M, Sanchez LJ, San Jose Gonzalez MA, Bamonde L, Garnelo L, Valdes L, Carreira JM, Moure J, Lopez SA: Exposure to paracetamol and asthma symptoms. Eur J Public Health 2013;23(4):706-710.

23. Atkinson HC, Stanescu I, Frampton C, Salem II, Beasley CP, Robson R: Pharmacokinetics and Bioavailability of a Fixed-Dose Combination of Ibuprofen and Paracetamol after Intravenous and Oral Administration. Clin Drug Investig 2015;35(10):625632.

24. Ziesenitz VC, Zutter A, Erb TO, van den Anker JN: Efficacy and Safety of Ibuprofen in Infants Aged Between 3 and 6 Months. Paediatr Drugs 2017;19(4):277-290. 